\title{
Detection of human papillomavirus in vulval carcinoma using semi-nested PCR and restriction enzyme typing: a rapid and sensitive technique
}

\author{
N H Cartwright, L J Sant Cassia, A J Easton, A G Morris
}

\begin{abstract}
Aims-To develop a highly sensitive technique for the reliable detection and typing of human papillomavirus (HPV) DNA in clinical tissue.

Methods-A two step, semi-nested PCR was used with primers spanning the $L 1$ region of the HPV genome and capable of detecting HPV DNA of all known HPV types. The clinical samples were typed by digestion of the 412 base pair PCR product with Rsa I, generating unique fragments for each HPV type. Thirteen samples were screened by this method, including nine vulval carcinoma samples and four wart samples from the penis and vulva.

Results-Experiments using DNA extracted from HPV DNA positive cell lines-that is, CaSki (HPV type 16) and HeLa (HPV type 18) established that the technique could detect as few as $50 \mathrm{HPV}$ copies and that the predicted Rsa I fragments from HPV types 16 and 18 were generated. The predicted 412 base pair fragment was observed for all 13 clinical samples subjected to semi-nested PCR. Rsa I digestion of the product of the second round of PCR permitted the positive identification of the HPV type in most cases.

Conclusions-This technique provides an effective and rapid means of detecting HPV DNA, in most cases providing the HPV type. High risk HPV types were always detected in the nine vulval carcinoma samples analysed. The amount of tissue available from the biopsy specimens was small, confirming the sensitivity of the method.

(F Clin Pathol: Mol Pathol 1996;49:M236-M239)
\end{abstract}

Keywords: HPV, semi-nested PCR, vulval carcinoma.

Human papillomavirus (HPV) infection is associated with several conditions, ranging from carcinoma to wart-like lesions, with certain HPV types preferentially associated with specific clinical outcomes. HPV types 6 and 11 are associated with benign genital warts $^{1-3}$ and laryngeal papillomas ${ }^{4}$ and are classed as low risk for the development of malignant tumours. Severe genital dysplasias and carcinomas are most frequently associated with HPV types 16 and 18 , and these are classed as high risk virus types. HPVs infecting the genitourinary tract are associated with sev- eral anogenital cancers, including carcinomas of the vulva, ${ }^{5-10}$ cervix $^{11-15}$ and penis. ${ }^{16-18} \mathrm{HPV}$ infection is now recognised as a major aetiological factor in these conditions. Sensitive detection and typing of HPVs, involved in both genital and cutaneous conditions, are essential factors in determining correlation between infection and disease.

The requirement for diagnostic techniques becomes increasingly necessary as the frequency of HPV infection becomes more evident. The detection of a wide range of HPV types is important for the determination of the prevalence of virus infection in clinical tissue. The polymerase chain reaction (PCR) has been the method most commonly used for the amplification of viral DNA in clinical tissue. ${ }^{19-22}$ The most widely used PCR involved the use of DNA primers that span a sequence of the HPV genome (L1 region) that is homologous to most, if not all, HPV types known, permitting the detection of a wide range of HPV types. It has been suggested that the sensitivity of this PCR may be limited and so a technique with greater sensitivity would be an advantage ${ }^{2324}$. For conditions such as vestibular vulvitis, ${ }^{25-28}$ which in some cases are associated with HPV infection, a sensitive and reliable test is needed.

The identification of the HPV type is also important and has been carried out previously using methods such as oligonucleotide probe hybridisation $^{29}{ }^{30}$ and Southern blot analysis ${ }^{31}$ in conjunction with PCR. Diagnostic restriction enzyme analysis, which does not involve the use of radioactivity, has frequently been used to identify HPV types in clinical tissue. ${ }^{43}$ Here, we report the use of a semi-nested PCR technique to detect HPV DNA in small amounts of clinical material, in conjunction with restriction enzyme analysis to identify the HPV type present.

\section{Methods}

SAMPLE SELECTION AND ISOLATION OF DNA Thirteen patient samples from the Walsgrave Hospital, Coventry, were included in the study. Nine of the patients had extensive vulval carcinoma. Four small biopsy samples from genital warts were also tested. Samples were placed on ice in RPMI 1640 immediately after removal.

DNA was extracted from the fresh tissue samples by finely chopping the material and incubating the samples overnight in fresh RPMI 1640 medium containing final concentrations of DNAse $(0.04 \mathrm{~g} / \mathrm{ml})$, hyaluronidase $(0.04 \mathrm{mg} / \mathrm{ml})$ and collagenase $(2 \mathrm{mg} / \mathrm{ml})$. The suspension was filtered and the supernatant 
centrifuged to pellet the cells. The pellet was washed twice in phosphate buffered saline (PBS) and the cells were lysed in Hirt's solution (10 $\mathrm{mM}$ Tris (hydroxymethyl)methylamine, $0.5 \%$ SDS, $20 \mathrm{mM}$ EDTA, $\mathrm{pH} 7.4$ ) for a minimum of six hours at $37^{\circ} \mathrm{C}$. Following phenol/chloroform extraction and ethanol precipitation, the DNA was resuspended in sterile distilled water and stored at $-20^{\circ} \mathrm{C}$.

\section{PCR AMPLIFICATION}

Amplification reactions were carried out using heat stable Taq polymerase. ${ }^{33}$ Reactions for the first round PCR contained aliquots of the clinical samples, control DNA (U138MG) or no DNA (water negative control) in $50 \mu \mathrm{l}$ of solutions containing 10x PCR buffer, $5 \mathrm{mM}$ $\mathrm{MgCl}_{2}$ (GibcoBRL, Paisley, UK), $0.25 \mathrm{mM}$ of each dNTP (dATP, dTTP, dGTP, and dCTP; Promega), 2 units Taq polymerase (GibcoBRL) and 15 pmoles/ 1 of each of the consensus PCR primers MY09 (5' ${ }_{7170}$ CGTCCMARRGGAWAGTGATC $\left._{7151} 3^{\prime}\right)$ and MY11 (5' ${ }_{6722}$ GCMCAGGGWCATAAYAATGG $\left.{ }_{6741} 3^{\prime}\right) .{ }^{19}$ The subscripts indicate the nucleotide positions in HPV type 16 DNA to which the oligonucleotides anneal. They are degenerate in several positions to allow for complementarity to each of the HPV types. ( $M$ denotes A plus $C ; R$ denotes $A$ plus $G$; $W$ denotes $A$ plus $T$; $Y$ denotes $\mathrm{C}$ plus $\mathrm{T}$.)

DNA from clinical samples was subjected to 30 cycles of amplification with a denaturation step at $94^{\circ} \mathrm{C}$ ( 30 seconds), an annealing step at $54^{\circ} \mathrm{C}$ (30 seconds) and a $72^{\circ} \mathrm{C}$ elongation step (30 seconds). The reaction was completed with a five minute elongation step at $72^{\circ} \mathrm{C}$. This procedure was designed to generate a fragment of approximately 450 base pairs in length from most HPV types. The amplified DNA product spans nucleotides $6722-7170$ in HPV type 16 and the corresponding regions of other genital HPVs.

In the semi-nested second round reaction, the primer MY09 was used in conjunction with a new second primer, R1 ( $5_{6758}$ CAATTATTTGTTACTGTGGTAGA ${ }_{6780} 3^{\prime}$ ) to reamplify the material generated in the first round, thus generating a 412 base pair fragment. An aliquot of the first round reaction product was added to a fresh PCR mix and subjected to a further 30 cycles of amplification. The conditions used were the same as previously but using an annealing temperature of $56^{\circ} \mathrm{C}$. This fragment was a suitable size for restriction enzyme typing. To reduce the risk of contamination, all manipulations were carried out in a class 2 microbiological hood, separate pipettes were used for the PCR reagents and DNA. Negative controls were set up first, followed by the samples and finally the positive controls.

\section{RESTRICTION ENZYME TYPING}

PCR amplified double stranded DNA was specifically cleaved using the restriction endonuclease Rsa I, as recommended by the manufacturer. Analysis of all available sequences of the HPV L1 region indicated that this enzyme generated characteristic restriction fragments from the purified 412 base pair product of the
Table 1 Rsa I restriction fragments predicted for the 412 base pair (bp) fragment from a number of HPV types. All $H P V$ sequence data available from the GenBank database were analysed to generate this table

\begin{tabular}{ll}
\hline HPV type & Restriction fragment sizes $(b p)$ \\
\hline 6 & $162,149,101$ \\
8 & 240,172 \\
11 & $216,136,34,26$ \\
16 & $311,70,31$ \\
18 & $136,125,85,38,28$ \\
30 & 326,86 \\
31 & 378,34 \\
33 & $236,103,39,34$ \\
34 & $186,162,59,5$ \\
35 & $338,42,32$ \\
40 & 327,85 \\
45 & $339,45,28$ \\
52 & 402,10 \\
53 & 403,9 \\
56 & 412 \\
57 & 412 \\
58 & 349,63 \\
59 & 412 \\
\hline
\end{tabular}

semi-nested PCR for most HPV types and could distinguish between different types, as indicated in table 1 .

\section{Results}

SEMI-NESTED PCR AMPLIFICATION OF CLINICAL SAMPLES

The sensitivity of the semi-nested PCR technique was investigated using DNA extracted from HPV DNA positive HeLa (HPV type 18) and CaSki (HPV type 16) cell lines. The results showed that the technique could detect HPV DNA in as few as 50 copies of the HPV genome (data not shown).

Figure 1 shows the results from eight of the vulval carcinoma samples examined. As can be seen with the first round PCR on the upper section of fig 1 , only the positive controls generated the expected 450 base pair fragment. The samples (fig 1, lanes 5-12) gave no amplified product. The lower section of fig 1 shows the second round semi-nested PCR. Fragments of the predicted size of 412 base pairs were seen in both of the positive controls and in all of the samples, indicating that all of the samples contained HPV DNA. This result illustrates the increased sensitivity of the seminested PCR technique, and confirmed that the semi-nested technique could detect HPV DNA where the standard technique failed. The additional vulval carcinoma sample and four wart biopsy specimens were also subjected to semi-nested PCR and found to contain HPV DNA (data not shown).

\section{RESTRICTION ENZYME TYPING OF CLINICAL}

\section{SAMPLES}

Restriction enzyme digestion of the PCR product generated from the second round with Rsa I was carried out in order to identify the HPV types present in the clinical samples. The digestion patterns of some of the more common HPV types likely to be encountered are shown in table 1. An additional enzyme(s) can be used to clarify the virus type further where necessary. In most of the clinical samples positive identification of the HPV type present was achieved. Figures 2 and 3 illustrate the digestion patterns produced from the eight vulval carcinoma samples shown to contain 


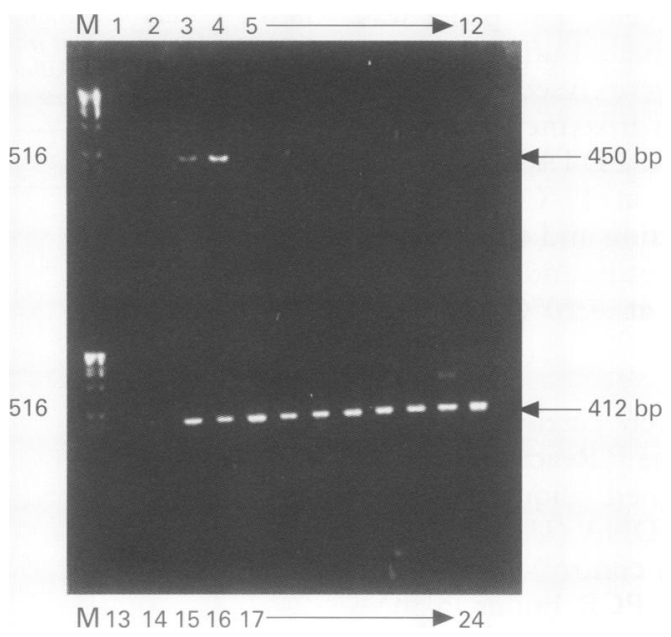

Figure $1 A 1.5 \%(w / v)$ agarose gel illustrating the results of semi-nested PCR amplification of eight vulval carcinoma patient samples. First round PCR primers MY09 and MY11 generated a 450 base pair (bp) fragment. Second round PCR primers generated a 412 bp fragment. Lane $M$ $=$ marker; lanes 1 and 13 = negative water controls for first and second round, respectively; lanes 2 and $14=U 138 M G$ cell line DNA negative control; lanes 3 and $15=\mathrm{HeLa}$ $D N A$ positive control; lanes 4 and $16=C a S k i$ DNA positive control; lanes 5-12 = first round PCR on samples 1-8; lanes 17-24 = semi-nested PCR on samples $1-8$.

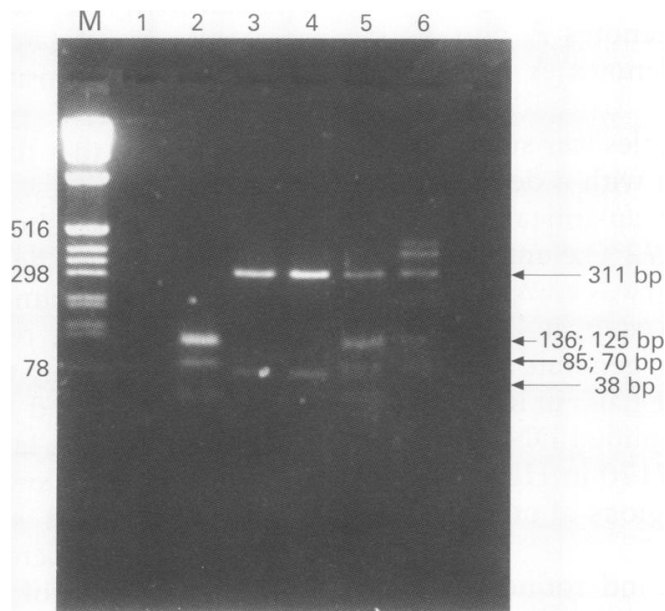

Figure 2 Restriction digestion patterns of positive controls and vulval carcinoma samples 1-3. Lane $M=$ marker; lane $2=\mathrm{HeL}$ a control; lane $3=\mathrm{CaSki}$ control; lanes 4-6 = samples 1-3. All digests were electrophoresed on a $2 \%$ $(w / v)$ agarose gel.

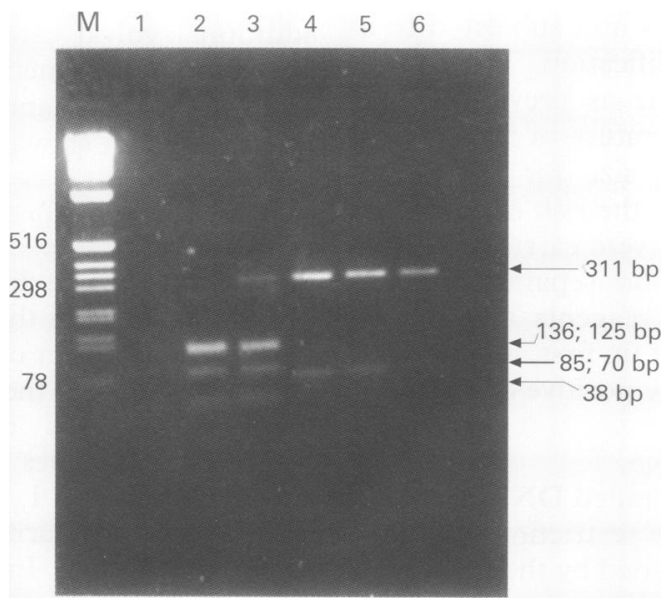

Figure 3 Restriction digestion patterns of vulval carcinoma samples 4-8. Lane $M=$ marker; lanes $2-6=$ samples 4-8. All digests were electrophoresed on a $2 \%$ (w/v) agarose gel.
Table 2 Typing of HPV DNA from clinical samples

\begin{tabular}{lll}
\hline Sample number & Sample type & HPV type \\
\hline 1 & Carcinoma resection & 16 \\
2 & Carcinoma resection & 16,18 \\
3 & Carcinoma resection & $16,18, \mathrm{U}^{\star}$ \\
4 & Carcinoma resection & 18 \\
5 & Carcinoma resection & 16,18 \\
6 & Carcinoma resection & 16 \\
7 & Carcinoma resection & 16 \\
8 & Carcinoma resection & 16 \\
9 & Carcinoma resection & 16 \\
10 & Penile wart biopsy & 16 \\
11 & Vulval wart biopsy & 6,16 \\
12 & Penile wart biopsy & 6,16 \\
13 & Penile wart biopsy & $16, \mathrm{U}^{\star}$ \\
\hline
\end{tabular}

^Unknown HPV type(s).

HPV DNA in fig 1. Figure 2 also shows the digestion patterns produced from the positive controls: HeLa (lane 2) and CaSki (lane 3). Samples 1 (fig 1, lane 4), 6 (fig 2, lane 4), 7 (fig 2 , lane 5 ), and 8 (fig 2 , lane 6 ) generated a pattern corresponding to that generated by the HPV type 16 positive CaSki cell line, indicating a single HPV type 16 infection in these samples. Sample 4 (fig 2, lane 2) gave the same digestion pattern as that seen with HeLa cell line DNA (HPV type 18) indicating a single HPV type 18 infection.

Samples 2 (fig 1, lane 5) and 5 (fig 2, lane 3) contained HPV types 16 and 18 DNA, while sample 3 (fig 1, lane 6) generated a pattern not seen in the other samples or predicted from known sequences of HPV. DNA fragments produced by this sample corresponded to both HPV types 16 and 18, and possibly another HPV type.

The restriction patterns found with some of the samples were more complex than others. The remaining five samples were also digested with Rsa I (data not shown). Sample 13 gave a digestion pattern that corresponded with the pattern produced by $\mathrm{CaSki}$ cell line DNA (HPV type 16) but also yielded fragments not corresponding to a known HPV type. However, the unidentified pattern was not the same as the unique fragments produced by sample 3 . A summary of the HPV types identified in the five samples is shown in table 2 , together with the results from patient samples $1-8$ (figs 2 and 3 ).

\section{Discussion}

The semi-nested PCR method has been used to detect various types of viruses in clinical specimens. $^{34}{ }^{35}$ The sensitivity of the seminested technique has previously been compared with single step PCR for detection of Dengue virus and it was shown that the two step system was more sensitive than the one step one..$^{35}$ Our results show that semi-nested PCR is capable of detecting as few as 50 copies of HPV DNA in the HeLa cell line (data not shown) and the increased sensitivity of the semi-nested PCR technique can be seen in fig 1 , where the first round PCR (equivalent to the L1 consensus PCR usually used to detect HPV DNA) failed to detect virus DNA in clinical samples. All of the clinical samples screened by semi-nested PCR were found to be positive for HPV DNA, while in the first round most of the samples were negative, confirming the greater sensitivity of the two step PCR method. ${ }^{34}{ }^{35}$ 
The fragment generated from the seminested PCR was an acceptable size for restriction enzyme analysis. Using Rsa I, restriction endonuclease analysis permitted the positive identification of HPV types in the clinical samples screened. High risk viruses were always detected in the nine vulval carcinoma samples. These results agree with previous findings that high risk viruses such as HPV types 16 and 18 are found in conditions such as vulval and cervical carcinoma, and therefore are the expected HPV types. ${ }^{72} 15$ The most common HPV type found in the vulval carcinoma samples was type 16 . This agrees with the work of Hording et al. ${ }^{7} \mathrm{HPV}$ type 6 was detected in two of the wart biopsy specimens, which also agrees with previous findings where low risk HPV types are mainly associated with benign infections. ${ }^{1-3}$ The technique developed here could be used to detect HPV DNA in a wide range of tissue types. On the whole, the method is robust and relatively fast (two days). The overall method is sensitive and avoids the use of radioactivity. Its main advantage is its sensitivity, permitting its use where only small quantities of tissue are available-for example, vestibular vulvitis. ${ }^{25-28}$

1 Oriel J. Natural history of genital warts. Br f Ven Dis 1971; 47:1-13.

2 Chow LT, Nasseri M, Wolinsky SM, Broker TR. Human papillomavirus types 6 and 11 mRNAs from genita condyloma acuminata. $f$ Virol $1987 ; 61: 2581-8$

3 Heinzel PA, Chan SY, Ho L, O'Connor M, Balaram P, Saveria T, et al. Variation of human papillomavirus type 6 (HPV 6) and HPV 11 genomes sampled throughout the world. F Clin Microbiol 1995;33:1746-54.

4 Salam MA, Rockett J, Morris A. General primer-mediated polymerase chain reaction for simultaneous detection and typing of human papillomavirus DNA in laryngeal typing of human papillomavirus DNA in laryngea

squamous cell carcinomas. Clin Otolaryngol 1994;20:84-8.
5 Planner RS, Hobbs JB. Intraepithelial and invasive neoplasia of the vulva in association with human papillomavirus infection. F Reprod Med 1988;33:503-9.

6 Kurman RJ, Toki T, Schiffman MH. Basaloid and warty carcinomas of the vulva. Am F Surg Pathol 1993;17:13345.

7 Hording U, Kringsholm B, Andreasson B, Visfield P, Dauggard $\mathrm{S}$. Human papillomavirus in vulvar squamous-cell carcinoma and in normal vulvar tissues: a search for a possible impact of HPV on vulvar cancer prognosis. Int $\mathcal{F}$ Cancer 1993;55:394-6.

8 Hording U. Human papillomavirus in epithelial neoplasia of the vulva and the uterine cervix. Dan Med Bull 1995;42:155-61.

9 Haefner HK, Tate JE, Mclachlin CM, Crum CP. Vulvar intraepithelial neoplasia: age, morphological phenotype, papillomavirus DNA and coexisting invasive carcinoma. Hum Pathol 1995;26:147-54

10 Monk BJ, Burger RA, Lin F, Parham G, Vasilev SA Wilczynski SP. Prognostic significance of human papillomavirus DNA in vulvar carcinoma. Obstet Gynecol 1995;85:709-15.

11 Reid R, Crum CP, Herchman BR, Shi Fu Y, Braun L, Shah $\mathrm{KV}$, et al. Genital warts and cervical cancer. Cancer 1984 53:943-53.

12 Crook T, Farthing A. Human papillomavirus and cervical cancer. Br f Hosp Med 1993;49:131-2.

13 De Roda Husman AM, Walboomers JMM, Meijer CJLM, Risse CJK, Schipper MEI, Helmerhorst TM, et al. Analysis of cytomorphologically abnormal cervical scrapes for the presence of 27 mucosotropic human papillomavirus using polymerase chain reaction. Int $f$ Cancer 1994 56:802-6.
14 Franco EL. Cancer causes revisited: human papillomavirus and cervical neoplasia. $\mathcal{F}$ Natl Cancer Inst 1995;87:779-80.

15 Xavier Bosch F, Manos MM, Munoz N, Sherman M, Jansen AM, Peto J, et al. Prevalence of human papillomaJansen AM, Peto J, et al. Prevalence of human papilloma-
virus in cervical cancer: a worldwide perspective. $\mathcal{F}$ Natl virus in cervical cancer: a wo

16 Arumainayagum JT, Sumathipala AHT, Smallman LA, Shahmanesh $M$. Flat condylomata of the penis presentin as patchy balanoposthitis. Genitourin Med 1990;66:251-3.

17 Hippelainen M, Yliskoski M, Saarikoski S, Syrjanen S, Syrjanen $\mathrm{K}$. Genital human papillomavirus lesions in the male sexual partners: the diagnostic accuracy of peniscopy. Genitourin Med 1991;67:291-6.

18 Hippelainen MI, Syrjanen S, Hippelainen MJ, Saarikoski S Syrjanen K. Diagnosis of genital human papillomavirus
(HPV) lesions in the male: correlation of peniscopy, histol(HPV) lesions in the male: correlation of peniscopy, histology and in

19 Manos MM, Ting Y, Wright DK, Lewis AJ, Broker TR, Wolinsky SM. Use of polymerase chain reaction amplification for the detection of genital human papillomaviruses. Cancer Cells 1989;7:209-14.

20 Snijders PJF, Van Der Brule AJC, Schrijnemakers HFJ, Snow G, Meijer CJLM, Walboomers JMM. The use of general primers in the polymerase chain reaction permits the detection of a broad spectrum of human papillomavirus genotypes. $f$ Gen Virol 1990;71:173-81.

21 Shamanin V, Delius H, De Villiers EM. Development of a broad spectrum PCR assay for papillomaviruses and its application in screening lung cancer biopsies. $\mathcal{f}$ Gen Virol 1994;75:1149-56.

22 Chan KW, Lam KY, Chan ACL, Lau P, Srivastava G. Prevalence of human papillomavirus types 16 and 18 in penile carcinoma: a study of 41 cases using PCR. 7 Clin Pathol 1994;47:823-6.

23 Williamson AL, Rybicki EP. Detection of genital human papillomaviruses by polymerase chain reaction amplificapapillomaviruses by polymerase chain reaction amplifica-
tion with degenerate nested primers. $f$ Med Virol tion with degener

24 Evander M, Edlund K, Boden E, Gustafsson A, Jonsson M, Karlsson R, et al. Comparison of a one-step and a two-step polymerase chain reaction with degenerate general primers in a population-based study of human papillomavirus infection in young Swedish women. $\mathcal{F}$ Clin Microbiol 1992; 30:987-92.

25 Friedrich EG. Vulvar vestibulitis syndrome. 7 Reprod Med 1987;32:110-14.

26 Turner MLC, Marinoff SC. Association of human papillomavirus with vulvodynia and the vulvar vestibulitis mavirus with vulvodynia and the vulv
syndrome. $\mathcal{F}$ Reprod Med 1988;33:533-7.

27 Umpierre SA, Kaufman RH, Adam E, Woods KV, Adlerstothz H. Human papillomavirus DNA in tissue biopsy specimens of vulvar vestibulitis patients treated with interferon Obstet Gynecol 1991;78:693-5.

28 Prayson RA, Stoler MH, Hart WR. Vulvar vestibulitis. $A m \mathcal{F}$ Surg Pathol 1995;19:154-60.

29 Jacobs MV, Husman AM, Van Der Brule AJC, Snijders PJF, Meijer CJLM, Walboomers JMM. Group-specific differentiation between high and low-risk human papillomavientiation between high and low-risk human papillomavi-
rus genotypes by general primer-mediated PCR and two rus genotypes by general primer-mediated PCR and two
cocktails of oligonucleotide probes. $\mathcal{F}$ Clin Microbiol 1995; cocktails of

30 Ylitalo N, Bergstrom T, Gyllensten T. Detection of genita human papillomavirus by single-tube nested PCR and type-specific oligonucleotide hybridisation. 7 Clin Microbiol 1995;33:1822-8.

31 Das C, Sharma JK, Gopalkrishna V, Das DK, Singh V, Gissman L, et al. A high frequency of human papillomavirus DNA sequences in cervical carcinomas of Indian women was revealed by Southern blot hybridisation and women was revealed by Southern blot hybridisation and

32 Chen SL, Han CP, Tsao YP, Lee JW, Yin CS. Identification and typing of human papillomavirus in cervical cancers in Taiwan. Cancer 1993;72:1939-45.

33 Saiki RK, Gelfand DH, Stoffel S, Scharf SJ, Higuchi R Horn GT, et al. Primer-directed enzymatic amplification of DNA with a thermostable DNA polymerase. Science 1988 239:487-91.

34 Okamoto M, Baba M, Kodama E, Sekine K, Tagaki T, Kasukawa $\mathrm{R}$, et al. Detection of hepatitis-C virus genome in human serum by multitargeted polymerase chain reacin human serum by multitargeted

35 Seah CLK, Chow VTK, Chan YC. Semi-nested PCR using NS3 primers for the detection and typing of Dengue viruses in clinical serum specimens. Clinical and Diagnostic Virology 1995;4:113-20. 